\title{
Morphological and genetic differentiation among Chilean populations of Bufo spinulosus (Anura: Bufonidae)
}

\author{
Diferenciación morfológica y genética entre poblaciones chilenas de Bufo spinulosus \\ (Anura: Bufonidae)
}

\begin{abstract}
MARCO A. MÉNDEZ ${ }^{1,2 *}$, EDUARDO R. SOTO ${ }^{2}$, CLAUDIO CORREA $^{1,3}$, ALBERTO VELOSO $^{2}$, ELISEO VERGARA $^{2}$, MICHEL SALLABERRY ${ }^{2} \&$ PATRICIA ITURRA ${ }^{3}$

${ }^{1}$ Laboratorio de Bioinformática y Expresión Génica y Laboratorio de Estadística, INTA, Universidad de Chile, Santiago, Chile

${ }^{2}$ Laboratorio de Vertebrados, Departamento de Ciencias Ecológicas, Facultad de Ciencias, Universidad de Chile, Santiago, Chile

${ }^{3}$ Programa de Genética Humana, ICBM, Facultad de Medicina, Universidad de Chile, Santiago, Chile

*Corresponding author: mmendez@inta.cl
\end{abstract}

\begin{abstract}
Bufo spinulosus has a wide and fragmented distribution range in Chile $\left(18^{\circ}\right.$ to $\left.33^{\circ} \mathrm{S}\right)$ along altitudinal and latitudinal gradients. Genetic variation was estimated using RAPD (Random Amplified Polymorphic DNA) markers in 10 populations from northern and central Chile. Morphometric and genetic information was analyzed as a function of geographical origin. The correlation between genetic and morphometric differentiation was analyzed by the Mantel test. An increase in body size as a function of latitude was observed. Specimens from El Tatio had the smallest body size and the greatest morphometric divergence. The AMOVA applied to genetic data indicated that $57.85 \%$ of the variance is explained by interregional differences and that $30.12 \%$ of the variance is found within populations. Low levels of within-regions genetic differentiation was observed in northern populations while higher levels of genetic differentiation was found in populations from central Chile. Mantel tests revealed a significant, positive correlation between genetic variation and geographic distance. When we excluded El Tatio population, Mantel test analyses showed significant correlations between morphological distance and genetic and geographic distances. We discuss whether water temperature could explain the morphological divergence observed in individuals from El Tatio.
\end{abstract}

Key words: amphibians, geographic variation, morphometry, RAPDs, AMOVA.

\section{RESUMEN}

Bufo spinulosus presenta una amplia y fragmentada distribución en Chile $\left(18^{\circ}\right.$ a $\left.33^{\circ} \mathrm{S}\right)$ a lo largo de gradientes altitudinales y latitudinales. La variación genética fue estimada utilizando marcadores RAPD ("Random Amplified Polymorphic DNA") en diez poblaciones del norte y centro de Chile. La información morfométrica y genética fue analizada en función de la procedencia geográfica. La correlación entre diferenciación genética y morfométrica fue analizada utilizando la prueba de Mantel. Se observó un incremento en el tamaño corporal en función de la latitud. Los individuos de El Tatio mostraron el tamaño corporal más pequeño y la mayor divergencia morfométrica. El AMOVA aplicado a los datos genéticos indicó que el 57,85\% de la varianza es explicada por diferencias entre regiones y que el $30,12 \%$ de la varianza se encuentra dentro de las poblaciones. Bajos niveles de diferenciación genética intrarregional fueron observados en las poblaciones del norte de Chile, mientras que las poblaciones de Chile central mostraron niveles más altos de diferenciación genética. Las pruebas de Mantel revelaron una correlación significativa y positiva entre la variación genética y la distancia geográfica. Cuando excluimos la población de El Tatio, las pruebas de Mantel mostraron correlaciones positivas y significativas entre las distancias morfológicas, genéticas y geográficas. Se discute si la temperatura del agua podría explicar la divergencia morfológica observada en los individuos de El Tatio.

Palabras clave: anfibios, variación geográfica, morfometría, RAPDs, AMOVA. 


\section{INTRODUCTION}

Amphibians have limited dispersal capability and high philopatry (Seppä \& Laurila 1999). These attributes allow the accumulation of genetic and morphological differences (Blouin \& Brown 2000, Camp et al. 2000, Miaud \& Merilä 2001) as well as in life-history traits (Berven \& Gill 1983, Laurila et al. 2001, Bernardo \& Reagan-Wallin 2002).

Bufo spinulosus (Wiegmann, 1835) has a wide geographic distribution, ranging from the Peruvian-Bolivian Altiplano to the eastern and western slopes of the Andes mountain range in Chile and Argentina (Cei 1962). In Chile this species is distributed between $18^{\circ}$ and $33^{\circ} \mathrm{S}$ latitude, with populations ranging from sea level (in the case of the Azapa locality in the Region I of Chile) to 2,000-4,600 meters of altitude for all other localities from north and central Chile. There are no descriptions of B. spinulosus populations between $23^{\circ}$ and $30^{\circ} \mathrm{S}$ latitude (Cei 1960, Veloso et al. 1982, Veloso \& Navarro 1988, Cortés et al. 1995). Population studies have demonstrated geographic variation in morphological and ecological characters (Cei 1960, Nuñez et al. 1982). For instance, Nuñez et al. (1982) found differences in the length of the digestive tract in $B$. spinulosus specimens from populations in San Pedro de Atacama and El Tatio, two localities situated only $65 \mathrm{~km}$ apart.

RAPD-PCR is a useful technique for identifying polymorphism (Williams et al. 1990) and for studying the population genetic structure of vertebrates (Hadrys et al. 1992). Moreover, it is technically straightforward and applicable to any organism without previous knowledge of its genome (Parker et al. 1998). Although RAPD's dominant expression somehow biases population genetic parameters and some assumptions are needed (Lynch \& Milligan 1994), cluster analysis is useful for detecting geographic patterns. In this sense, RAPD markers have the advantage of allowing screening a high number of polymorphic markers for population studies (Parker et al. 1998).

In this paper, we aimed to determine the extent of genetic differentiation of $B$. spinulosus in Chile using RAPD markers, and to evaluate whether correlations exist between morphological variation with abiotic factors and genetic differentiation.

\section{MATERIAL AND METHODS}

Specimens of Bufo spinulosus were collected along a latitudinal and an altitudinal gradient, from 10 localities of north and central Chile, between November 2000 and December 2001 (Fig.1): Parinacota $\left(18^{\circ} 12^{\prime} \mathrm{S}, 6^{\circ} 16^{\prime} \mathrm{W} ; 4,445\right.$ $\mathrm{m}$ of altitude; $\mathrm{n}=23$ ); Putre (18 $11^{\circ}$ ' S, 69033' $\mathrm{W} ; 3,507 \mathrm{~m}$ of altitude; $\mathrm{n}=15)$; Azapa $\left(18^{\circ} 30^{\prime}\right.$ $\mathrm{S}, 70^{\circ} 13^{\prime} \mathrm{W} ; 164 \mathrm{~m}$ of altitude; $\mathrm{n}=12$ ); El Tatio $\left(22^{\circ} 20^{\prime} \mathrm{S}, 68^{\circ} 01^{\prime} \mathrm{W} ; 4,264 \mathrm{~m}\right.$ of altitude; $\mathrm{n}=$ 22); Chita $\left(22^{\circ} 25^{\prime} \mathrm{S}, 68^{\circ} 10^{\prime} \mathrm{W}\right.$; 3,741 $\mathrm{m}$ of altitude; $\mathrm{n}=13$ ); Vilama $\left(22^{\circ} 52^{\prime} \mathrm{S}, 68^{\circ} 10^{\prime} \mathrm{W}\right.$; $2,579 \mathrm{~m}$ of altitude; $\mathrm{n}=21)$; Jerez $\left(23^{\circ} 11^{\prime} \mathrm{S}\right.$, $67^{\circ} 59^{\prime} \mathrm{W}, 2,513 \mathrm{~m}$ of altitude; $\mathrm{n}=14$ ); Portillo ( $32^{\circ} 51^{\prime} \mathrm{S}, 70^{\circ} 10^{\prime} \mathrm{W} ; 2,119 \mathrm{~m}$ of altitude; $\mathrm{n}=8$ ); Farellones $\left(33^{\circ} 21^{\prime} \mathrm{S}, 70^{\circ} 18^{\prime} \mathrm{W} ; 2,331 \mathrm{~m}\right.$ of

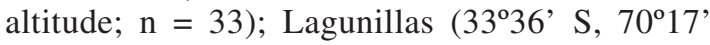
$\mathrm{W} ; 2,242 \mathrm{~m}$ of altitude; $\mathrm{n}=11$ ). Specimens were deposited in the Herpetology Collection of the Departamento de Biología Celular y Genética de la Universidad de Chile (DBGUCH).

The following morphometric traits were measured in adult specimens: (1) snout-vent length; (2) head width; (3) head height; (4) mandible width; (5) forelimb length; (6) foot length; (7) tibia length; (8) femur length; (9) nostril-mouth distance; (10) nostril-eye distance; (11) interorbital width; (12) mouthinterorbital axis distance; (13) parotid diameter; (14) internostril distance; (15) eye diameter; (16) tympanum diameter; and (17) head length. Measurements were taken to the nearest 0.05 $\mathrm{mm}$ using a caliper. Each trait was $\log _{10}$ transformed to conduct parametric statistic analyses.

Geographic variation of morphological characters was assessed using ANOVA, Principal Components Analysis (PCA), and Stepwise Discriminant Analysis (DA). A matrix of misclassifications (Jackknife option) was estimated using locality as a discriminating factor. All morphological analyses were performed using SYSTAT 5.0 (Wilkinson 1996).

Eighty seven individuals were included in the RAPD analysis. Ten individuals were screened per locality, except for Azapa and Lagunillas where only three and four individuals were studied, respectively.

DNA was extracted from the toe tissues of each individual, using the phenol-chloroform (1:1) and chloroform-isoamyl alcohol (24:1) method (Sambrook et al. 1989). PCR was conducted using: $1.64 \mu \mathrm{L}$ of $\mathrm{H}_{2} 0 ; 1.5 \mu \mathrm{L}$ of buffer (10X); $0.75 \mu \mathrm{L}$ of $\mathrm{MgCl}_{2}(50 \mathrm{mM})$; $0.18 \mu \mathrm{L}$ of dNTPs (10 mM of each one); 6.25 $\mu \mathrm{L}$ of primer (1.2 $\mathrm{mM}$ ) (OPERON Technologies); $0.18 \mu \mathrm{L}$ of Taq Gibco (5U/ $\mu \mathrm{L})$ and $4.2 \mu \mathrm{L}$ of DNA (10ng $\left.\mu \mathrm{L}^{-1}\right)$. The thermal profile for RAPD reactions was: 2 min at $95^{\circ} \mathrm{C}$, followed by six cycles of $1 \mathrm{~min}$ at $94{ }^{\circ} \mathrm{C}, 1 \mathrm{~min}$ at $35^{\circ} \mathrm{C}$, and $2 \mathrm{~min}$ at $72{ }^{\circ} \mathrm{C}$, 


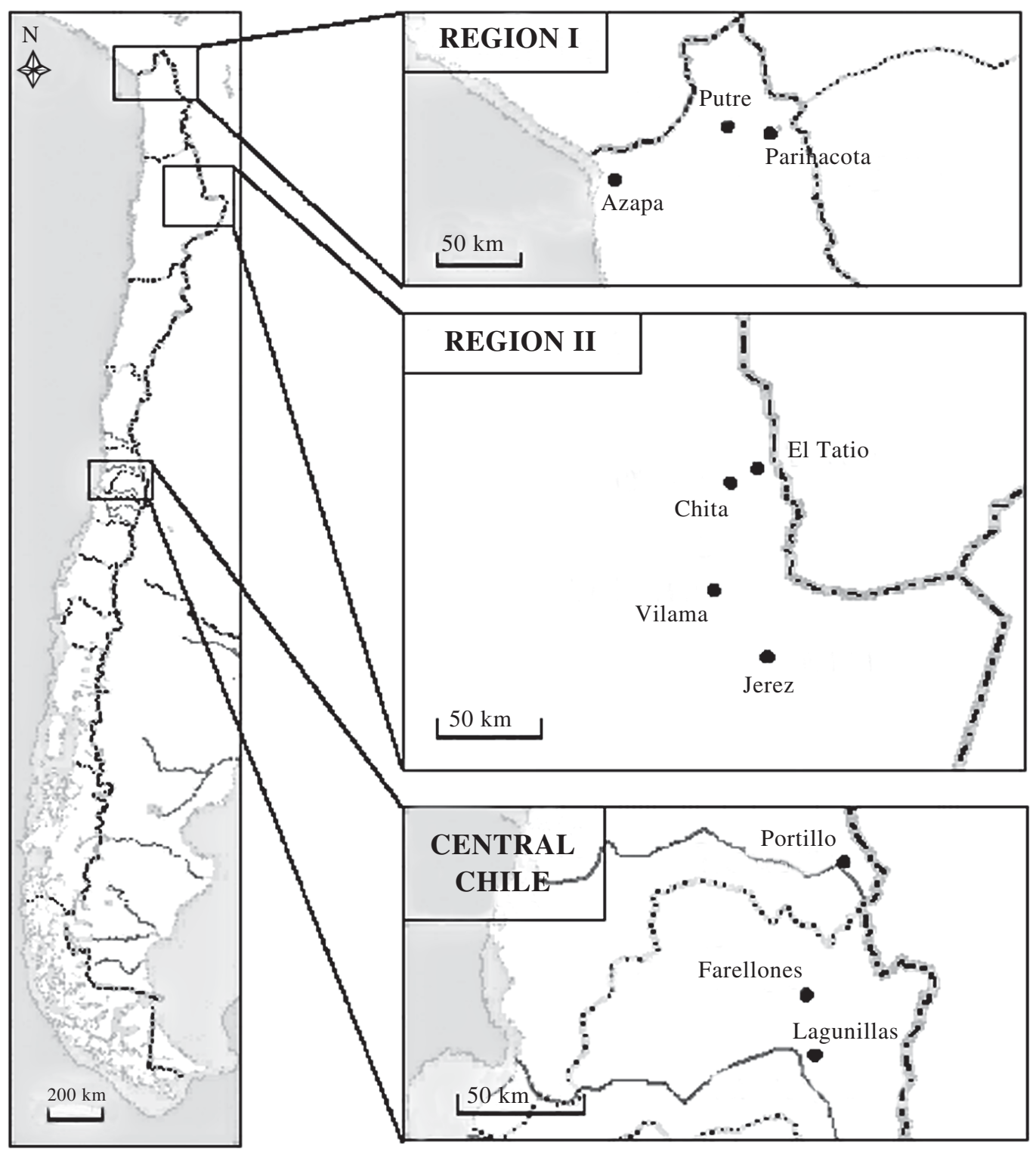

Fig. 1: Map of localities where individuals of Bufo spinulosus were collected.

Mapa de las localidades donde los individuos de Bufo spinulosus fueron recolectados.

followed by 30 additional cycles of $10 \mathrm{~s}$ at 94 ${ }^{\circ} \mathrm{C}, 30 \mathrm{~s}$ at $35^{\circ} \mathrm{C}$ and $1 \mathrm{~min}$ at $72{ }^{\circ} \mathrm{C}$, and a final extension at $72{ }^{\circ} \mathrm{C}$ for $5 \mathrm{~min}$. Six primers out of 10 assayed were selected by their consistency and band pattern quality (Table 1). PCR products were run in agarose $(1.5 \%)$ at $7.5 \mathrm{~V} \mathrm{~cm}^{-1}$ in TBE buffer $0.5 \mathrm{X}(10$ $\mathrm{mM}$ Tris, $\mathrm{pH} 7.5,50 \mathrm{mM} \mathrm{NaCl}, 0.1 \mathrm{mM}$
EDTA) with ethidium bromide. Resulting bands were UV-visualized and photographed.

The consistency of the RAPD profiles was tested on each primer by reanalyzing them at least three times in a subsample. Genetic analyses were performed using AMOVA (Excoffier et al. 1992) and POPGENE (Yeh \& Boyle 1997). POPGENE was used to create a 


\section{TABLE 1}

Sequences of primers used in RAPD-PCR analysis and the number of informative bands (loci) utilized. The number of analyzed bands corresponds to the number of resulting bands following application of the Lynch \& Milligan correction (1994)

Secuencias de los partidores utilizados en los análisis de RAPD-PCR y número de bandas informativas (loci) utilizadas. El número de bandas analizadas corresponde al número resultante siguiendo la corrección de Lynch \& Milligan (1994)

\begin{tabular}{ccc}
\hline Primer name & Sequence & Number of analyzed bands \\
\hline OPB-08 & 5'-GTCCACACGG-3' & 17 \\
OPB-10 & 5'-CTGCTGGGAC-3' & 15 \\
OPB-11 & 5'-GTAGACCCGT-3' & 11 \\
OPG-05 & 5'-CTGAGACGGA-3' & 15 \\
OPG-06 & 5'-GTGCCTAACC-3' & 14 \\
OPG-14 & 5'-GGATGAGACC-3' & 12 \\
\hline
\end{tabular}

UPGMA cluster based on Nei distances (Nei 1972) and FREETREE (Pavlicek et al. 1999) to create a UPGMA cluster based on Rogers' distances. Bootstrap analysis $(1,000$ pseudoreplicates) was used to evaluate statistical nodal support.

Mantel Test 2.0 (Liedloff 1999) was used to determine the significance of correlations using matrices of pairwise distances between populations, with 2,000 randomizations. We used the following distance matrices in these analyses: (a) the morphological matrix of morphometric distances among populations (we used the canonical scores of group means of each population resulting from DA analysis); (b) the genetic matrix of Nei's genetic distances calculated by the POPGENE program, using the option for dominant markers; (c) the geographic matrix, calculated using the program "Surface distance between two points of latitude and longitude" (available at: www.wcrl.ars.usda.gov/cec/java/latlong.htm); and (d) the altitude matrix, based on altitudinal measurements at each locality, using data obtained from a GPS (Garmin Ettrex). Original values of the different matrices were transformed to Euclidian distances.

\section{RESULTS}

No sex-linked differences were detected in body size. Nevertheless, significant differences exist in body size among populations as a function of locality (ANOVA: $\mathrm{F}_{9,161}=72.756$; $\mathrm{P}<0.0001)$. In general, body size showed an increase as a function of latitude, with smaller sized individuals corresponding to the El Tatio locality, while individuals from central Chile were significantly larger than individuals from Regions I and II.
The first three axes of PCA conducted on 16 quantitative morphological characters explained $98.07 \%$ of the variance. All characters had positive values and similar weights.

A graphic representation of the eigenvalues of the first two components revealed strong morphological differentiation in individuals from El Tatio (Fig. 2), which were clearly differentiated from all other individuals in the morphometric space. It was also possible to differentiate between populations from the north (Regions I and II) and populations from central Chile. DA of morphometric traits using locality as the discriminating variable, revealed significant differences among populations (Wilk's lambda $=0.139 ; \mathrm{F}_{18,320}=29.877 ; \mathrm{P}=$ $0.0001)$. Classification matrices correctly distinguished specimens from El Tatio, Lagunillas and Farellones, with high values (95, 100 and $67 \%$, respectively). Low values (below $40 \%$ ) were found in other populations.

RAPD analysis included 84 polymorphic bands after the correction of Lynch \& Milligan (1994). The partitioning of AMOVA indicated a $57.85 \%$ differentiation at the regional level (Region I, Region II, and central Chile), 30.12 $\%$ within populations, and only $12.03 \%$ was explained by variance among populations.

The greatest genetic differentiation detected in central Chile corresponded to Farellones and Lagunillas populations $\left(\varnothing_{\mathrm{st}}=0.4028\right)$, while the lowest value was observed between Farellones and Portillo $\left(\varnothing_{\mathrm{st}}=0.3172\right)$. The lowest value of population differentiation in Region II was found between Vilama and Chita populations $\left(\varnothing_{\mathrm{st}}=0.0977\right)$, while Jerez and Chita populations registered the highest value $\left(\varnothing_{\text {st }}=0.5024\right)$. Values of $\varnothing_{\text {st }}$ ranged from 0.1352 to 0.4143 among the other populations from Region II. The greatest value of differentiation within Region I was recorded 


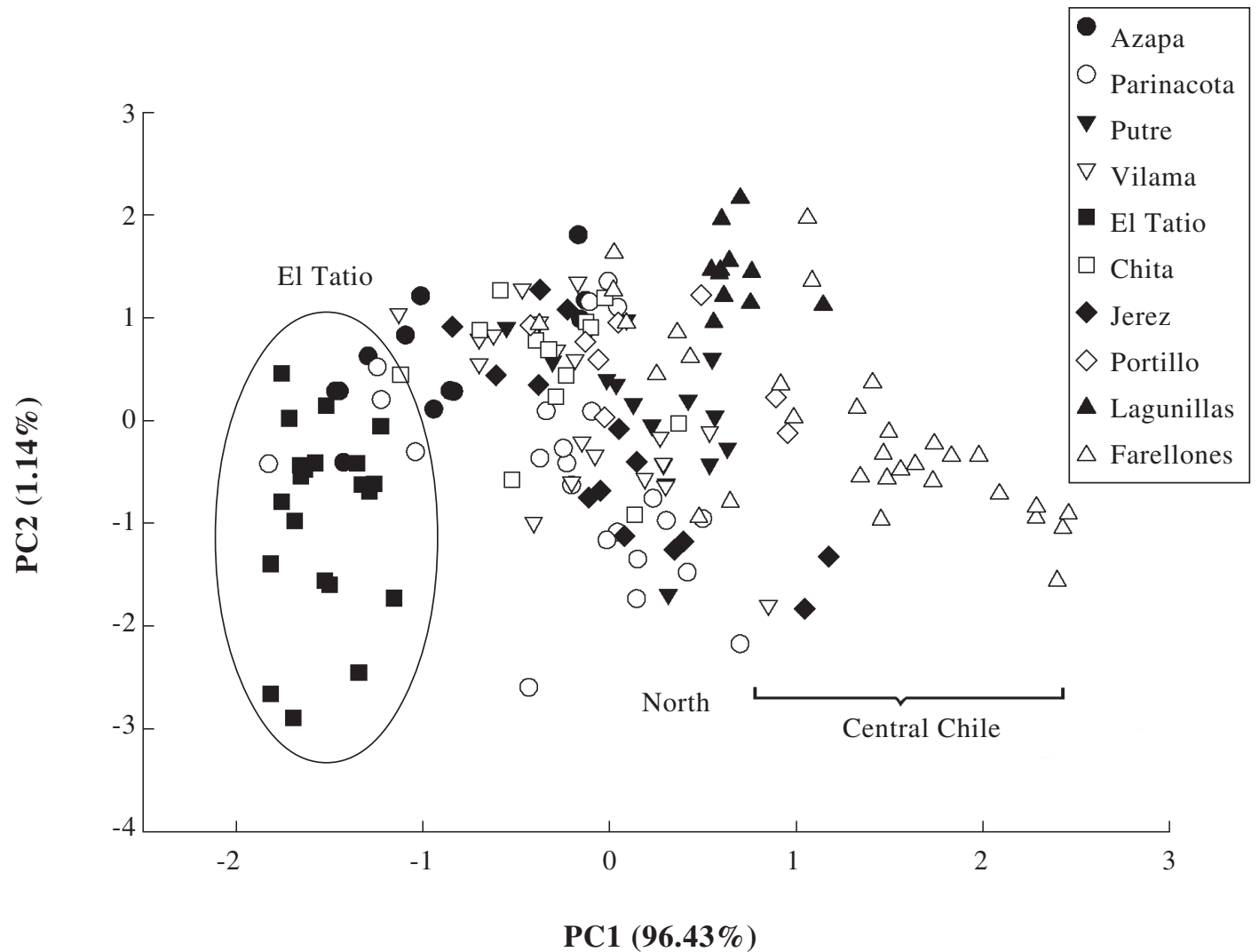

Fig. 2: Principal Components Analysis (PCA) of 16 morphometric characters measured in 10 populations of Bufo spinulosus. Values in parentheses correspond to percentages of explained variance.

Análisis de Componentes Principales (PCA) de 16 caracteres morfométricos medidos en 10 poblaciones de Bufo spinulosus. Los valores entre paréntesis corresponden a los porcentajes de varianza explicada.

for Azapa and Putre populations $\left(\varnothing_{\mathrm{st}}=0.3186\right)$, whereas the lowest value $\left(\varnothing_{\mathrm{st}}=0.1313\right)$ was found between Parinacota and Putre, suggesting limited genetic differentiation.

Cluster analyses based on Rogers distances confirmed the genetic differentiation observed among the three main regions as indicated by its bootstrap support (bootstrap values: Region I, $99 \%$; Region II, $100 \%$; and central Chile, $100 \%$; Fig. 3). However, when populations were analyzed, genetic differentiation was found only for the Azapa population in Region I (58 $\%)$, the Jerez population in Region II (63\%), and the Lagunillas population in central Chile (62 \%). Bootstrap values for all of the remaining populations were below $50 \%$.

Correlation values for Mantel tests of genetic distances, morphological data, geographic distances and altitude are given in
Table 2. Significant correlations were found only between matrices of genetic distances and geographic distances $(\mathrm{r}=0.65, \mathrm{P}<0.005$, Table 2). When the morphologically divergent population of El Tatio was excluded, the correlation between the genetic and geographic distance matrices increased $(\mathrm{r}=0.76, \mathrm{P}<$ 0.005). Significant correlations between morphology and both genetic and geographic distances was also found when the El Tatio population was excluded (morphologicalgenetic, $\mathrm{r}=0.47, \mathrm{P}<0.005 ;$ morphologicalgeographic, $\mathrm{r}=0.32, \mathrm{P}<0.005)$.

\section{DISCUSSION}

The high levels of genetic differentiation among Regions I, II, and central Chile indicated by AMOVA and cluster analyses of 


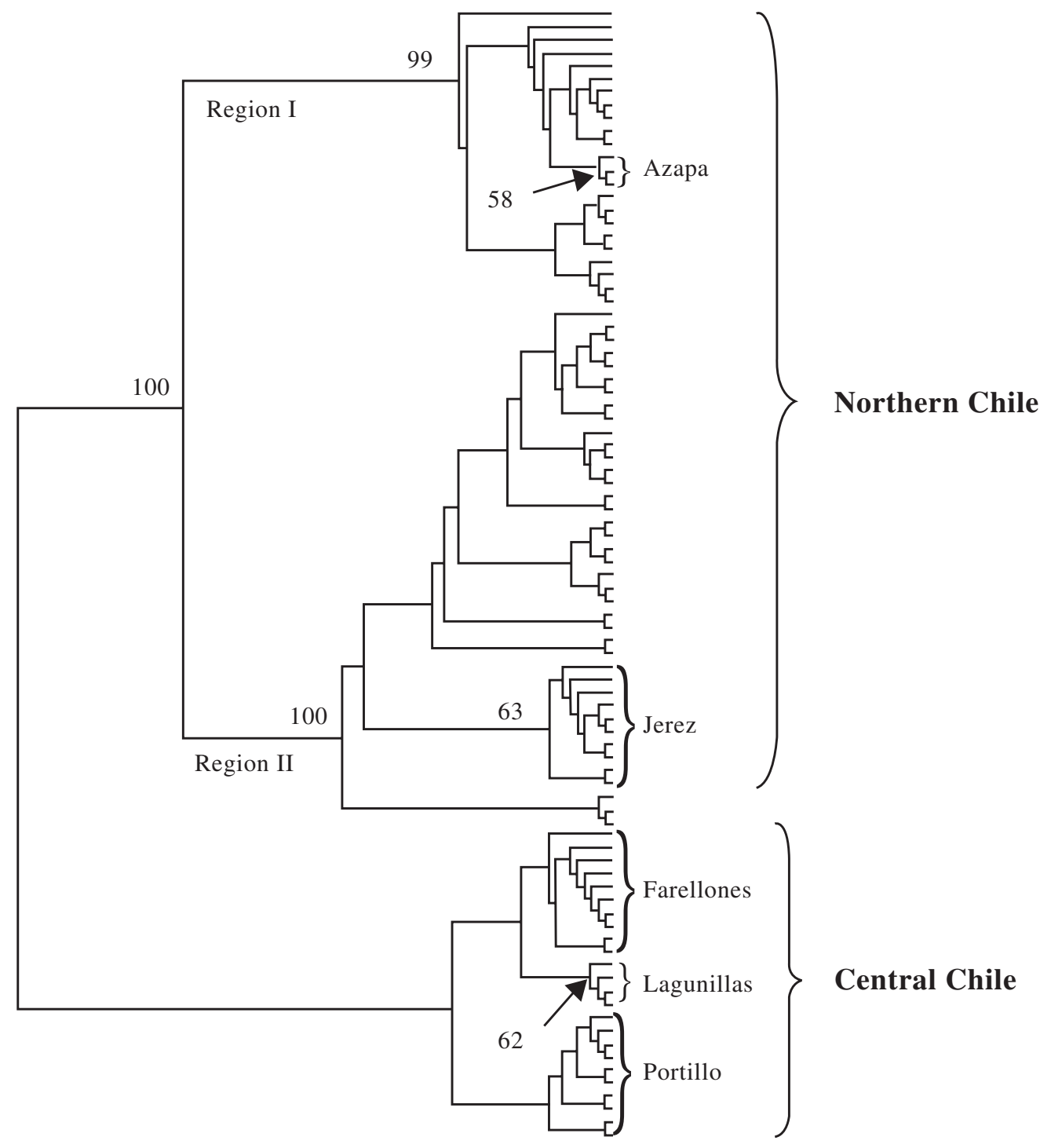

Fig. 3: UPGMA cluster analysis based on Rogers distances for 85 individuals belonging to 10 populations of Bufo spinulosus. Numbers above nodes represent bootstrap values obtained from 1,000 pseudoreplicates.

Análisis de UPGMA basado en las distancias de Rogers para 85 individuos pertenecientes a 10 poblaciones de Bufo spinulosus. Números sobre los nodos representan los valores de bootstrap obtenidos de 1.000 pseudorréplicas.

RAPD markers, suggest a strong geographic structure. This was expected considering the evaluated scale $(1,677 \mathrm{~km}$ between the most distant localities) and the restricted mobility of amphibians (Berven \& Grudzien 1990, Beebee 1996). Rowe et al. (2000) described a similar pattern of genetic divergence as a function of distance in Bufo calamita.

The smallest specimens were found in El Tatio population whereas individuals from central Chile were larger than northern ones.
The multivariate morphological divergence was high among regions while low levels within regions were found. No significant correlations between morphometric differentiation and latitudinal or genetic differentiation were found by analyzing matrix data of all populations. However, when El Tatio population was excluded, positive correlations were found (Table 2). Although correlation does not imply causality, it suggests that among-region morphological differentiation as well as in 


\section{TABLE 2}

Summary of Mantel tests performed between matrices of geographic (GeogDist), morphological

(MorpDist) altitude (Altit Dist) and genetic (GenDist) distances. All analyses were carried out using the program Mantel 2.0 (Liedloff 1999) with 1,000 permutations. The analyses were performed first comparing all populations and then excluding the El Tatio population, which presented the greatest morphological divergence

Resumen de las pruebas de Mantel realizadas entre las matrices de distancias geográficas (GeogDist), morfológicas (MorpDist) de altitud (Altit Dist) y genéticas (GenDist). Todos los análisis fueron llevados a cabo usando el programa

Mantel 2,0 (Liedloff 1999) con 1.000 permutaciones. Los análisis fueron realizados primero comparando todas las poblaciones y luego sin la población de El Tatio, la cual presentó la mayor divergencia morfológica

\begin{tabular}{|c|c|c|c|c|c|c|}
\hline \multirow[b]{2}{*}{ Matrix } & \multicolumn{3}{|c|}{ All populations } & \multicolumn{3}{|c|}{ Excluding El Tatio } \\
\hline & g & $\mathrm{R}$ & $\mathrm{P}$ & g & $\mathrm{r}$ & $\mathrm{P}$ \\
\hline MorpDist x AltitDist & 0.494 & 0.112 & $>0.05$ & 1.2 & 0.29 & $>0.05$ \\
\hline MorpDist x GenDist & -2.325 & -0.2558 & $>0.05$ & 3.15 & 0.47 & 0.005 \\
\hline MorpDist $\mathrm{x}$ GeogDist & -0.353 & -0.0483 & $>0.05$ & 4.514 & 0.32 & 0.005 \\
\hline GenDist $\mathrm{x}$ AltitDist & 0.235 & 0.0288 & $>0.05$ & -0.321 & -0.04 & $>0.05$ \\
\hline GenDist $x$ GeogDist & 4.241 & 0.65 & 0.005 & 4.40 & 0.76 & 0.005 \\
\hline
\end{tabular}

genetic composition may result from restrictions to gene flow. Cei (1962) proposed that there is geographic isolation between populations from north and central Chile, caused by climatic barriers (principally xeric conditions), which could affect the distribution range of this species. Our data are in agree with this proposition. However, high levels of gene flow were detected among populations within regions as indicated by the $\varnothing_{\text {st }}$ values for northern populations. Such a pattern could be associated to larval or adult dispersal due to sporadic flooding caused by the El Niño Southern Oscillation (Messerli et al. 1993, Vargas et al. 2000, Garreaud et al. 2003). The distance between rivers fluctuates between 3-9 $\mathrm{km}$ for Region I and 3-13 km for Region II, thus making possible the connection of populations during flooding events. An alternative explanation for the low levels of genetic differentiation in northern populations emphasizes recent colonization events in the area. Thus, the distribution of RAPD markers in Regions I and II could result from incomplete or recent isolation among populations. Data at hand makes impossible to discriminate between these alternatives or to identify a general mechanism to explain the observed pattern. The use of mitochondrial markers (e.g., control region) could shed some light in this regard.

The morphometric divergence and genetic homogeneity of El Tatio population can be addressed by considering abiotic factors, since larval development occurs in streams having water temperatures between $25{ }^{\circ} \mathrm{C}$ and $30{ }^{\circ} \mathrm{C}$ during all day long. At other localities, temperatures fluctuate between $15{ }^{\circ} \mathrm{C}$ and 25 ${ }^{\circ} \mathrm{C}$ during the day and remain around $7{ }^{\circ} \mathrm{C}$ at night (Benavides 2003). Although pH differences could also account for differences in larval development, information is scarce and has only been described in Rana arvalis (Räsänen et al. 2003). We favor the probable effect of water temperature on morphology and larval development, since it is a relevant factor affecting body size in ectotherms (Atkinson 1996). Warmer waters induce a smaller size at metamorphosis, which, in turn, determines a smaller adult size as described in Rana sylvatica (Berven 1990), Rana cascadea (Blouin \& Brown 2000), Desmognathus quadramaculatus (Camp et al. 2000), and Discoglossus galganoi (Alvarez \& Nicieza 2002), among others (but see Laugen et al. 2003). Ongoing experimental evidence will shed light on water temperature as a causative factor affecting body size in Bufo spinulosus.

\section{ACKNOWLEDGMENTS}

Financial support was provided by FONDECYT grants 3000048/2000 to MAM. SAG (Servicio Agrícola Ganadero) supplied collecting permits (Resolution number 3085/2000). ERS thanks CONICYT for fellowship support. We are also grateful to Paula Neill and two referees for useful suggestions and comments on an earlier version of the manuscript. 


\section{LITERATURE CITED}

ÁLVAREZ D \& AG NICIEZA (2002) Effects of temperature and food quality on anuran larval growth and metamorphosis. Functional Ecology 16: 640-648.

ATKINSON D (1996) Ectotherm life-history responses to developmental temperature. In: Johnston IA \& AF Bennett (eds) Animals and temperature: phenotypic and evolutionary adaptation: 183-204. Cambridge University Press, Cambridge, United Kingdom.

BEEBEE TJC (1996) Ecology and conservation of amphibians. Chapman and Hall, London, United Kingdom. 214 pp.

BENAVIDES AG (2003) Biología térmica de Bufo spinulosus (Anura: Bufonidae): una comparación intraespecífica. Tesis de Doctorado, Facultad de Ciencias, Universidad de Chile, Santiago, Chile. vii+93 pp.

BERNARDO J \& NL REAGAN-WALLIN (2002) Plethodontid salamanders do not conform to "general rules" for ectotherm life histories: insights from allocation models about why simple models do not make accurate predictions. Oikos 97: 398-414.

BERVEN KA (1990) Factors affecting population fluctuation in larval and adult stages of the wood frog (Rana sylvatica). Ecology 71: 1,599-1,608.

BERVEN KA \& DE GILL (1983) Interpreting geographic variation in life-history traits. American Zoologist 23: 85-97.

BERVEN KA \& TA GRUDZIEN (1990). Dispersal in the wood frog (Rana sylvatica), implications for genetic population structure. Evolution 44: 2,047-2,056.

BLOUIN MS \& ST BROWN (2000) Effects of temperature-induced variation in anuran larval growth rate on head width and leg length at metamorphosis. Oecologia 125: 358-361.

CAMP C, JL MARSHALL \& RM AUSTIN (2000) The evolution of adult body size in black-bellied salamanders (Desmognathus quadramaculatus complex). Canadian Journal of Zoology 78: 1,7121,722 .

CEI J (1960) Geographic variation of Bufo spinulosus in Chile. Herpetologica 16: 243-250.

CEI J (1962) Batracios de Chile. Ediciones de la Universidad de Chile, Santiago, Chile. cviii + 128 pp.

CORTÉS A, JC TORRES-MURA, L CONTRERAS \& C PINO (1995) Fauna de los vertebrados de los Andes de Coquimbo: cordillera de Doña Ana. Ediciones Universidad de La Serena, La Serena, Chile. 108 pp.

EXCOFFIER L, P SMOUSE \& JM QUATTRO (1992) Analysis of molecular variance inferred from metric distances among DNA haplotypes: Application to human mitochondrial DNA restriction data. Genetics 131: 479-491.

GARREAUD R, M VUILLE \& A CLEMENT (2003) The climate of the Altiplano: observed current conditions and mechanisms of past changes. Palaeogeography Palaeoclimatology Palaeoecology 194: 5-22.

HADRYS H, M BALICK \& B SCHIERWATER (1992) Applications of random amplified polymorphic DNA (RAPD) in molecular ecology. Molecular Ecology 1: 55-63.

LAUGEN A, A LAURILA \& J MERILÄ (2003) Latitudinal and temperature-dependent variation in embryonic development and growth in Rana temporaria. Oecologia 135: 548-554.

LAURILA A，P CROCHET \& J MERILÄ (2001) Predation induced effects on hatchling morphology in the common frog (Rana temporaria). Canadian Journal of Zoology 79: 926-930.

LIEDLOFF A (1999) MANTEL, Mantel nonparametric test calculator. Version 2.0.

LYNCH M \& BG MILLIGAN (1994) Analysis of population genetic structure with RAPD markers. Molecular Ecology 3: 91-99.

MESSERLI B, B GROSJEAN, G BONANI, A BÜRGI, MA GEYH, K GRAF, K RAMSEYER, H ROMERO, U SCHOTTERER, H SCHREIER \& M VUILLE (1993) Climate change and natural resource dynamics of the Atacama Altiplano during the last 18,000 years: a preliminary synthesis. Mountain Research and Development 13: 117-127.

MIAUD C \& J MERILÄ (2001) Local adaptation or environmental induction? Causes of population differentiation in alpine amphibians. Biota 2: 31-50.

NEI M (1972) Genetic distances between populations. American Naturalist 106: 283-292.

NÚÑEZ H, MA LABRA \& J YÁÑEZ (1982) Hábitos alimentarios de dos poblaciones andinas de Bufo spinulosus Wiegmann, 1835 (Anura: Bufonidae). Boletín del Museo Nacional de Historia Natural de Chile 39: 81-91.

PARKER P, A SNOW, M SCHUG, G BOOTON \& P FUERST (1998) What molecules can tell us about populations: choosing and using a molecular marker. Ecology 79: 361-382.

PAVLICEK A, S HRDA \& J FLEGR (1999) FreeTreeFreeware program for construction of phylogenetic trees on the basis of distance data and bootstrap/ jackknife analysis of the tree robustness. Application in the RAPD analysis of the genus Frenkelia. Folia Biologica (Praha) 45: 97-99.

RÄSÄNEN K, A LAURILA \& J MERILÄ (2003) Geographic variation in acid tolerance of the moor frog, Rana arvalis. I. Local adaptation. Evolution 57: 352-362.

ROWE G, TJC BEEBEE \& T BURKE (2000) A microsatellite analysis of natterjack toad (Bufo calamita) metapopulations. Oikos 88: 641-651.

SAMBROOK J, E FRITSCH \& T MANIATIS (1989) Molecular cloning: a laboratory manual. Second edition. Cold Springs Harbor Press, Cold Springs Harbor, New York, USA. 1,659 pp.

SEPPÄ P \& A LAURILA (1999) Genetic structure of island populations of the anurans Rana temporaria and Bufo bufo. Heredity 82: 309-317.

VARGAS G, L ORTLIEB \& J RUTLLANT (2000) Aluviones históricos en Antofagasta y su relación con eventos El Niño/Oscilación del Sur. Revista Geológica de Chile 27: 157-176.

VELOSO A, M SALLABERRY, J NAVARRO, P ITURRA, J VALENCIA, M PENNA \& N DÍAZ (1982) Contribución sistemática al conocimiento de la herpetofauna del extremo norte de Chile. In: El hombre y los ecosistemas de montaña: 135-265. MAB 6. Santiago, Chile.

VELOSO A \& J NAVARRO (1988) Lista sistemática y distribución geográfica de anfibios y reptiles de Chile. Bolletino del Museo Regionale di Scienze Naturali, Torino 6: 481-593. 
WILKINSON L (1996) SYSTAT 5: the system for statistics. SYSTAT, Inc., Evanston, Illinois, USA.

WILLIAMS JG, AR KUBELIK, KJ LIVAK, JA RAFALSKI \& SV TINGEY (1990) DNA polymorphisms amplified by arbitrary primers are useful as genetic markers. Nucleic Acids Research 18: $6,531-6,535$

YEH FC \& TJB BOYLE (1997) Population genetic analysis of co-dominant and dominant markers and quantitative traits. Belgian Journal of Botany 129: 157.

Associate Editor: Milton Gallardo

Received March 4, 2004; accepted June 30, 2004 